\title{
FEDERAL CIVIL PROCEDURE: ANTI-INJUNCTION STATUTE'S APPLICATION TO CIVIL RIGHTS CASES
}

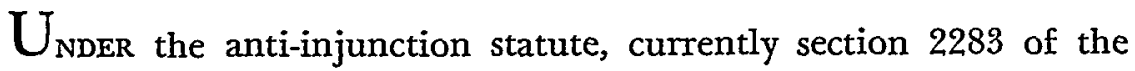
Judicial Code, a federal court is expressly denied the power to enjoin proceedings pending in a state court "except as expressly authorized by Act of Congress, or where necessary in aid of its jurisdiction, or to protect or effectuate its judgments." 1 This section applies the common law principle of comity ${ }^{2}$ to pending state proceedings. Comity is in essence a recognition that deference to the court asserting jurisdiction over a matter is necessary to prevent friction in our federal system. A corollary of comity is the tenet that in the delicate area of state criminal proceedings only exceptional circumstances and danger of irreparable injury should evoke interference. ${ }^{3}$

The decisions in two recent civil rights cases have afforded federal courts the opportunity to re-examine the scope and function of the anti-injunction statute. The most recent of these cases, Dilworth $v$. Riner, ${ }^{4}$ involved state criminal prosecutions for viola-

128 U.S.C. $\$ 2283$ (1964). (Emphasis added.)

If the defendant is prosecuted in a state court, his attempt to get an injunction from a federal court will usually be accompanied by an effort to transfer the proceedings to that court under the removal statutes. See 28 U.S.C. $\$ \$ 1441-50$ (1964). In civil rights cases, the applicable section is 28 U.S.C. $\$ 1443$ (1964). Removal is automatic, but the district court judge has power to remand to the state courts, 28 U.S.C. $\$ 1447$ (c) (1964). The Civil Rights Act of 1964, $\$ 901$, made remand orders appealable in civil rights cases. 28 U.S.C. $\$ 1447$ (d) (1964).

2 "[Comity is] ... a doctrine which teaches that one court should defer action on causes properly within its jurisdiction until the courts of another sovereignty with concurrent powers, and already cognizant of the litigation, have had an opportunity to pass upon the matter." Darr v. Burford, 339 U.S. 200, 204 (1950). See Kline v. Burke Constr. Co., 260 U.S. 226, 229-30 (1922); Wells Fargo \& Co. v. Taylor, 254 U.S. 175, 183 (1920); Covell v. Heyman, 111 U.S. 176, $182-83$ (1884); Philip Peck \& Co. v. Jenness, Gage \& Co., 48 U.S. (7 How.) 611, 624-25 (1849); Hagan v. Lucas, 35 U.S. (10 Pet.) 400, 403 (1836); IA Moore, Federal Practice f 0.202 (2d ed. 1961); Warren, Federal and State Court Interference, 43 HARv. L. Rev. 345, 359-66 (1930).

The source of the doctrine is English. See 2 StORY, Equity JURISPRUDENCE 201-11 (13th ed. 1886).

${ }^{3}$ See, e.g., Wilson v. Schnettler, 365 U.S. 381, 385-86 (1961); Stefanelli v. Minard, 342 U.S. 117, $120 \cdot 21$ (1951); Douglas v. City of Jeannette, 319 U.S. 157, 162-64 (1943). See 1A MOore, Federal Practice [0.230[1] (2d ed. 1961); Federal Injunctions Against State Criminal Proceedings, 4 Stan. L. REv. 381 (1952).

"If these considerations limit federal courts in restraining State prosecutions merely threatened, how much more cogent are they to prevent federal interference with proceedings once begun." Stefanelli v. Minard, supra, at 122-23.

- 343 F.2d 226 (5th Cir. 1965). 
tions of a trespass statute ${ }^{5}$ resulting from restaurant sit-ins. ${ }^{0}$ The plaintiffs alleged that the public accommodations title of the Givil Rights Act of $1964^{7}$ constituted an expressly authorized exception to the anti-injunction statute, and thus sanctioned the enjoining of their prosecutions. In the Dilworth context, three parts of the act were relevant: section 201 (a) accords Negroes the right to receive service in a restaurant; ${ }^{8}$ section 203 (c) provides that "no person" shall punish or attempt to punish Negroes for exercising this right; ${ }^{9}$ and section 204 (a) permits a federal court to enjoin such

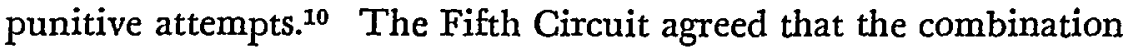
of these provisions fell within the anti-injunction statute's exceptive proviso, ${ }^{11}$ and that any considerations of comity had been "abrogated" by Congress in the Civil Rights Act. ${ }^{12}$

Prior to the Dilworth decision, the possibility of an exception to the anti-injunction statute had been posed in Baines $v$. City of Danville. ${ }^{13}$ The plaintiffs were being criminally prosecuted in Virginia for violations of picketing and parade ordinances resulting from racial demonstrations. ${ }^{14}$ They alleged that the ordinances were unconstitutional and petitioned the federal courts to enjoin the proceedings, ${ }^{15}$ asserting that section 1983 of Title 42 of the United States Code, ${ }^{16}$ which confers equity jurisdiction upon federal courts to provide relief for any person deprived of federal constitutional rights under color of state law, ${ }^{17}$ constituted an exception

${ }^{5}$ Miss. CODE ANN. $\$ 2087.5$ (Supp. 1964).

6343 F.2d at 228.

778 Stat. 241, 42 U.S.C. $\$ 2000$ a (1964).

8 "All persons shall be entitled to the full and equal enjoyment of the goods, services, facilities, privileges, advantages, and accommodations of any place of public accommodation, as defined in this section, without discrimination or segregation on the ground of race, color, religion, or national origin." 78 Stat. 243 , 42 U.S.C. $\S 2000$ a (a) (1964).

- "No person shall ... punish or attempt to punish any person for exercising or attempting to exercise any right or privilege secured by section 201 or 202." 78 Stat. 244, 42 U.S.C. $\$ 2000 \mathrm{a}-2$ (1964).

10 "Whenever any person has engaged . . . in any act or practice prohibited by section 208, a civil action for preventive relief, including an ... injunction, ... may be instituted by the person aggrieved ...." 78 Stat. 244, 42 U.S.C. $\$ 2000 a-03 a$ (1964).

11343 F.2d at $230-31$.

12 Id. at 232.

13337 F.2d 579 (4th Cir. 1964), cert. denied, 381 U.S. 939 (1965).

14 Id. at $583-85$.

${ }^{15} I d$. at $582-83$.

${ }^{16}$ Civil Rights Act of 1871, $\S 1$, Rev. StaT. $\$ 1979$ (1875), 42 U.S.C. $\S 1983$ (1964).

${ }^{17}$ For a discussion of the vitality of $\S 1983$, see Note, Section 1983: A Givil Remedy for the Protection of Federal Rights, 39 N.Y.U.L. REv. 839 (1964). 
within the meaning of the anti-injunction statute..$^{18}$ In a divided opinion, the Fourth Circuit held that the state court prosecution could not be enjoined. ${ }^{19}$

To discern whether the decisions in Dilworth and Baines are proper applications of the anti-injunction statute, its historical context must be examined. The statute has its origins in the Judiciary Act of 1793, which read: "nor shall a writ of injunction be granted to stay proceedings in any court of a state ...."20 In spite of this well-established congressional mandate against interference with state courts, numerous exceptions were gradually developed by

${ }^{18}$ Accord, Cooper v. Hutchison, 184 F.2d 119, 124 (3d Cir. 1950) (no analysis of the point); Kabath v. O'Connor, 234 F. Supp. 917, $921-22$ (E.D.N.Y. 1964) ( 2283 bars the injunction unless petitioner can show he cannot otherwise protect his constitutional rights); Tribune Review Publishing Co. v. Thomas, 153 F. Supp. 486, 490 (W.D. Pa. 1957) (no analysis); cf. Zellner v. Lingo, 218 F. Supp. 513, 518 n.2 (M.D. Ala. 1963) (court could circumvent $\$ 2283$ by "in aid of its jurisdiction" provision). Contra, Goss v. Illinois, 312 F.2d 257, 259 (7th Cir. 1963) (little analysis); Smith v. Village of Lansing, 241 F.2d 856, 859 (7th Cir. 1957) (no analysis); Sexton v. Barry, 233 F.2d 220, 226 (6th Cir. 1956) (no analysis); Alexander Bird in the Ground v. District Court, 239 F. Supp. 981-84 (D. Mont. 1965) (following Baines); Chaffee v. Johnson, 229 F. Supp. 445, 447 (S.D. Miss. 1964) (no analysis); Island Steamship Lines, Inc. v. Glennon, 178 F. Supp. 292,295 (D. Mass. 1959) (little analysis); $c f$. Wojcik v. Palmer, 318 F.2d 171 (7th Cir. 1963) (court sustained $\$ 2283$ bar as not in aid of jurisdiction or to protect judgment, but did not discuss possibility of $\S 1983$ being an excepting statute).

Under the predecessors of $\$ 2283$, compare Aultman \& Taylor Co. v. Brumfield, 102 Fed. 7 (N.D. Ohio 1900), 'appeal dismissed, 22 Sup. Ct. 938 (1902) and Mickey v. Kansas City, 43 F. Supp. 739 (W.D. Mo. 1942), with Tuchman v. Welch, 42 Fed. 548, 557-59 (C.C.D. Kan. 1890).

10337 F.2d at 595-96.

${ }^{30}$ Act of March 2, 1793, ch. 22, $\$ 5,1$ Stat. 334. The statute was amended in 1874, when an exception to allow injunctions in bankruptcy proceedings was added. Rev. STar. $\$ 720$ (1875). Precisely why this exception and no other was added to the anti-iujunction statute in 1874 is a difficult matter to determine. The various removal statutes, emanating from the Judiciary Act of 1789 , ch. $20, \S 12,1$ Stat. 79, provided that the state courts should "proceed no further," and the Shipowners' Limited Liability Act, ch. 43, $\$ 4,9$ Stat. 635 (1851), provided that "all claims and proceedings against the owner or owners shall cease." "Yet these were not expressly excepted. The answer may be that the Bankruptcy Act, ch. 176, §21, 14 Stat. 526 (1867) provided that proceedings "shall . . . be stayed," and thus seemed to sanction a technical change in the anti-injunction statute whereas the others would require more of a substantive change, a result which, the revision of the statutes was not intended to produce. See 2 CoNG. REc. 646 (1874) (remarks of Congressman Poland). Alternatively, the Cominittee on Revision of the Laws may have fortuitously seen the conflict with the Bankruptcy Act but overlooked the others. (The change was proposed by the Chairman on the floor. See 2 CoNG. REc. 999 (1874).) It would appear that the express inclusion of the bankruptcy exception did not raise an inference that other exceptions were excluded. See Durfee \& Sloss, Federal Injunction Against Proceedings in State Courts: The Life History of a Statute, 30 Mrch. L. REv. 1145, 1149 n.15 (1932), calling the single exception merely a "direction of the political wind." But see Taylor \& Willis, The Power of Federal Courts to Enjoin Proceedings in State Courts, 42 YALE L.J. 1169, 1175 n.37 (1933), pointing out that such an inference is plausible. 
federal court decisions. ${ }^{21}$ Some injunctions were justified on the rationale that other federal statutes, while not specifically mentioning the anti-injunction statute, nevertheless pro tanto effected amendments to it. ${ }^{22}$ In 1941, however, the Supreme Court in Toucey $v$. New York Life Ins. $\mathrm{Co}^{23}$ revitalized the statute by sweeping away virtually all the prior non-statutory exceptions. Thereafter, Congress amended the anti-injunction statute in 1948 to its present form for the express purpose of reestablishing the decisional law as it had existed prior to the Toucey decision. ${ }^{24}$

The Supreme Court has considered the scope of the anti-injunction statute three times since its revision. In Capital Service, Inc. v. $N L R B,{ }^{25}$ the Court allowed an injunction under the provision authorizing a federal court to make an exception "where necessary in aid of its jurisdiction." 26 In Amalgamated Clothing Workers of America v. Richman Bros., ${ }^{27}$ a five-man majority indicated that "the prohibition [of the anti-injunction statute] is not to be whittled away by judicial improvisation." ${ }^{28}$ But two years later, in Leiter Minerals, Inc. v. United States, ${ }^{29}$ the Court held that the statute did not apply at all when the United States was a party, which seems to indicate at least a slight retreat from the stringent holding in Richman Bros. ${ }^{30}$

${ }^{21}$ For general discussion of the judicial history, see Toucey v. New York Life Ins. Co., 314 U.S. 118 (1941); Hart \& WechsLER, The Federal Courts and the Federal System 1075-78 (1953); MOORE, COMMENTARY on the Judicial CODE T 0.03 (49) (1949); 1A MOORE, Federal Practice TI 0.208-230 (2d ed. 1961); Durfee \& Sloss, supra note 20; Taylor \& Willis, supra note 20; Warren, Federal and State Court Inteference, 43 Harv. L. Rev. 345 (1930); Note, 74 HaRv. L. Rev. 726 (1961).

${ }_{22}^{2}$ See Toucey v. New York Life Ins. Co., supra note 21, at 132-34. Other exceptions to the anti-injunction statute were totally products of the judiciary. See id. at 134-39.

${ }_{23} 314$ U.S. 118 (1941).

24 "Therefore the revised section restores the basic law as generally understood and interpreted prior to the Toucy [sic] decision." H.R. REP. No. 308, 80th Cong., 1st Sess. AI82 (1947). But see Amalgamated Clothing Workers v. Richman Bros., 348 U.S. 511, 515 n.l (1955), suggesting that the quoted phrase does not refer to the statutory exceptions, but only to the judicially-created exceptions.

25 347 U.S. 501 (I954).

${ }_{20}$ "We do not stop to consider the many questions which have been propounded under this newly worded provision of the Code." Id. at 505.

27348 U.S. 511 (1955).

28 Id. at 514 .

The three dissenters felt that $\S 2283$ was narrower than the pre-1948 version. "To read $\$ 2283$ literally-as the majority opinion does-ignores not only this legislative history but also over a century of judicial history." Id. at 523 (dissenting opinion). ${ }^{2} 352$ U.S. 220 (1957).

${ }^{30}$ See id. at 225-26. It is perhaps significant that Richman Bros. is nowhere cited in the opinion. 
Whatever may have been the original reasons for its enactment, ${ }^{31}$ the present statute pragmatically reflects the policies of prevention of friction and maintenance of state-court power to make orderly disposal of cases within their competence. ${ }^{32}$ This has been the historical interpretation of the statute's broad-gauge purpose by the courts, and the Revisor's Note to the 1948 revision at least tacitly approves such an interpretation. ${ }^{33}$ The strength of these policies, however, has been under constant erosion. The broadening of the exceptions by the 1948 revision and the purely judicial exception created in Leiter Minerals clearly indicate that the trend is away from any strict policy of noninterference.

These same policies, and the same erosion of them, are germane to the judicial concept of comity. ${ }^{34}$ The test which the Supreme Court has evolved to govern any federal interference with state criminal proceedings requires that exceptional circumstances and imminent, irreparable injury exist. ${ }^{35}$ This test has evolved, of course, from cases in which application of the anti-injunction statute was not at issue. ${ }^{36}$

Both Dilworth and Baines take a somewhat novel approach to the relationship between comity and section 2283. Where the statute applies, the question of exception is one of statutory interpretation, ${ }^{37}$ and judicial principles of comity can only be used as an

\footnotetext{
${ }^{81}$ It has been suggested that the statute was enacted in response to pressures of state sovereignty, Warren, supra note 21, at 347-48; that it was to reduce the work load of federal judges, Taylor \& Willis, supra note 20, at 1170; and that it was the result of a dislike for equity jurisdiction, Toucey v. New York Life Ins. Co., 314 U.S. at 131-32.

${ }^{82}$ See Amalgamated Clothing Workers v. Richman Bros., 348 U.S. 511, 518-19 (1955).

${ }^{83}$ See note 24 supra.

34 For the underlying policies of comity, see note 2 supra.

The erosion can be seen in such cases as Dombrowski v. Pfister, 380 U.S. 479, 48392 (1965) (injunction allowed against prosecution of petitioner under unconstitutional statute); Bush v. Orleans Parish School Bd., 194 F. Supp. 182 (E.D. La.), aff'd mem. sub nom. Tugwell v. Bush, 367 U.S. 907 (1961) (same); Browder v. Gayle, 142 F. Supp. 707, 713 (M.D. Ala. 1956), aff'd mem. 352 U.S. 903 (1957) (same).

${ }^{85}$ Dombrowski v. Pfister, supra note 34, at 484-85; Cleary v. Bolger, 371 U.S. 392, 397 (1963); Wilson v. Schnettler, 365 U.S. 381,385 (1961); Stefanelli v. Minard, 342 U.S. 117, 122 (1951); Douglas v. City of Jeannette, 319 U.S. 147, 163 (1943); Watson v. Buck, 313 U.S. 387, 400 (1941); Spielman Motor Sales Co. v. Dodge, 295 U.S. 89, 95 (1935).

${ }^{80}$ This distinction has often escaped the lower courts, and has caused them to rely too heavily on these cases in situations involving $\$ 2283$. See note 38 infra and text accompanying notes 37-39.

${ }^{87}$ The only possible constitutional provision that might compel noninterference is the eleventh amendment. Its inapplicability was permanently decided by the Supreme Court in Ex parte Young, 209 U.S. 123 (1908).
} 
aid to finding legislative intent. ${ }^{38}$ Under this approach it would thus be improper for a court, after a finding that Congress intended a statute to be an exception to section 2283 in the situation under consideration, to hold that comity nevertheless forbids interference. ${ }^{39}$

Finding legislative intent, however, is usually difficult. Even when the statute was revised in 1948 "to cover all [statutory] exceptions," 40 some of the statutes which the courts had recognized as exceptions referred to section 2283 only obliquely at best. ${ }^{41}$ Thus it is usually said that a statute need not refer specifically to the anti-injunction statute to be an exception. ${ }^{42}$ Nor must it necessarily make reference to injunctions. ${ }^{43}$ The explicit exceptive requirements have not been delineated by the courts.

The Dilworth court had little difficulty solving the problem. The three provisions of the Civil Rights Act of 1964, taken together, lead inexorably to the conclusion that injunctions against pending state proceedings were contemplated. ${ }^{44}$ The Fifth Circuit

s8 "If a subsequent act of the Congress is an implied repeal of [\$ 2283] . . . it cannot reasonably be said not to have modified a judicially fashioned rule [comity] which, at best, is coextensive with the earlier statute." $337 \mathrm{~F} .2 \mathrm{~d}$ at 591 . "[Comity is] . . . a rule that may be abrogated by the Congress . . . . Section 207 (a) of the [1964 Civil Rights] Act provides [an aggrieved party need not exhaust his state remedies before seeking federal relief] . . . This provision, together with $\$ \$ 203$ (c) and 204 (a), plainly abrogates the comity rule ...." 348 F.2d at 232 .

${ }^{30}$ While comity cannot compel noninterference, considerations analogous to comity may underlie congressional intent. See text accompanying note 51 infra.

${ }^{30}$ H.R. REP. No. 308, 80th Cong., 1st Sess. A181 (1947).

i1 Even the bankruptcy provision then in effect, Bankruptcy Act of 1938, $\$ 11$, ch. 575, 52 Stat. 849, 11 U.S.C. $\$ 29$ (a) (1964), did not expressly authorize stays of state proceedings: "A suit . . . which is pending . . . shall be stayed . . . " Similarly, the Shipowners' Limited Liability Act, ch. 521, §3, 49 Stat. 1480 (1936), 46 U.S.C. \$ 185 (1964), provided simply that "all claims and procecdings against the owner . . shall cease." The Frazier-Lemke Farm-Mortgage Act $\$ 6(5)(2)$, ch. 792, 49 Stat. 944 (1935), states that "the court shall stay all judicial or official proceedings in any court . . . ." All of these were recognized statutory exceptions at the time of the revision. Sce Toucey v. New York Life Ins. Co., 314 U.S. 118, 132-34 (1941); HART \&: WECHSLER, op. cit. supra note 21, at 1076; Note, 74 Harv. L. REv. 726, 737 (1961).

42 See, e.g., Amalgamated Clothing Workers v. Richman Bros., 848 U.S. 511, 516 (1955).

43 See note 41 supra.

* The Supreme Court held in Hamm v. City of Rock Hill, 379 U.S. 306 (1964), 1965 DUKE L.J. 640, that states could not prosecute persons who exercised rights under the act. Section 203 (c) clearly states persons shall not be punished nor shall an attempt be made to punish them for exercising this right. "There is nothing in this express interdiction which could be construed as meaning that appellants may be punished by prosecution in a state trial court so long as they may later vindicate their right not to be punished in a state appellate court or in the United States Supreme Court. They may simply not be punished and prosecution is punishment." $343 \mathrm{~F} .2 \mathrm{~d}$ at 231. The court might more easily have said "prosecution is an attempt to punish." 
therefore assumed that Congress considers federal court vindication of the rights created by the Civil Rights Act to be more important than the friction caused by interference with the state courts in any case arising under the act. As an interpretation of the Civil Rights Act, the approach was a a proper one: It would be presumptuous under these circumstances for a court to consider the effects of interference in deciding whether an exception had been established by Congress.

The statute involved in Baines, section 1983, is much more difficult to analyze. In considering whether it was an exception, the court attempted to devise a mechanical test to solve the problem. Looking at the recognized exceptions to section 2283, the court found that all save one ${ }^{45}$ were "at the least, thoroughly incompatible with a literal application of the anti-injunction statute." 46 Section 1983, however, was not necessarily incompatible. "Creation of a general equity jurisdiction is in no sense antipathetic to statutory or judicially recognized limitations upon its exercise."47

It is submitted that the Baines approach is not a proper one. The court's focal issue being the question of congressional intent, it is not sufficient to point out that there is no necessary incompatibility between the two statutes; rather the inquiry should be directed at whether Congress desired violations of civil rights to be redressed even where that meant enjoining a pending state court proceeding. Several facts lend credence to an argument that Congress would indeed have approved an injunction in this section 1983 context. The legislative history of the statute supports this view; ${ }^{48}$ recent

\footnotetext{
4The exception which is difficult to reconcile is Porter v. Dicken, 328 U.S. 252 (1946), which allowed an injunction against the execution of a state court order of ejectment in a suit brought by the Price Administrator under the Emergency Price Control Act $\$ 205$ (a), 56 Stat. 33 (1942). The statute authorized the Administrator to sue in "the appropriate court," and the Supreme Court held that this should be construed to allow the Administrator an option to sue either in the state or federal courts, and that if he chose the latter, the federal court could enjoin any pending state proceeding. 328 U.S. at 254-55. Since the Administrator could have sought the injunction in the state court, there was no necessary conflict between the Emergency Price Control Act and the anti-injunction statute. The court in Baines distinguishes this case by reasoning that the Administrator represented the United States. $337 \mathrm{~F}, 2 \mathrm{~d}$ at 589. However, Leiter Minerals, note 29 supra and accompanying text, had not yet been decided.

10337 F.2d at 589.

17 Ibid.

48 Congress envisioned the possibility of a usurpation of state court functions: "This section, like the first, absorbs the entire jurisdiction of the States over their local and domestic affairs ...." Cong. Globe, 42d Cong., 1st Sess. 366 (1871) (remarks of Congressman Arthur). "[The bill] ... does not even give the State courts a chance
} 
Supreme Court decisions construe the statute as fully in force; ${ }^{40}$ and a grant of equity jurisdiction had significance in 1871, as the distinction between law and equity was a viable one at that time. These are the factors which should have been analyzed by the court, even if their persuasiveness were to be ultimately disregarded.

The danger obviously envisaged by the courts in finding that section 1983 is an exception to section 2283 is that it will open the door to continual distuption of orderly state proceedings by criminal defendants seeking federal interference whenever they can allege a deprivation of constitutional rights. 50 This danger can be eliminated, however, by a restricted interpretation of section 1983 in its relationship to section 2283. It is reasonable to assume that Congress in 1871 approved interference with the state courts only under exceptional circumstances and where irreparable injury was imminent. Such an interpretation not only is probably in accord

to try questions .... It takes the whole question away from them in the beginning." Cong. Globe APPENDIX, 42d Cong., lst Sess. 86 (1871) (remarks of Congressman Storm).

The statute was being enacted regardless of potential interference with state administration of justice: "I believe that it [the federal government] can extend its powers, through its courts, in times of peace, directly to the individual citizen who is deprived of his rights, privileges, and immunities, whether through the positive act or the default of the State authorities." CoNg. Globe, 42d Cong., Ist Sess. 367-68 (1871) (remarks of Congressman Sheldon). "Federal laws and Federal rights must be pro. tected whether domestic laws or their administration are interfered with or not, because the Constitution and the laws made in pursuance thereof are the supreme law of the land." Id. at 502 (remarks of Senator Frelinghuysen). "If the States shall fail to secure and enforce this right of the colored man, and deny to him protection in the free exercise and enjoyment of it as a citizen of the State, then the United States, by virtue of his national citizenship, must and will, by appropriate legislation, by all the power of its courts, by its land and naval forces, extend over him within the States the shield of the national authority." Id. at 609 (remarks of Senator Pool).

There appears to have been no desire to protect orderly disposition of cases in the state courts, for the legislation was expressly stimulated by the failure of these courts to act properly: "Shall it be said that the citizen may be wrongfully deprived of his life, liberty, and property in his own country and at his own homestead, and the national arm cannot be extended to him because there is a State government whose duty it is to afford him redress, but refuses or neglects to discharge that duty?" Id. at 368 (remarks of Congressman Sheldon).

${ }^{\circ}$ E.g., Griffin v. School Bd., 377 U.S. 218 (1964); McNeese v. Board of Educ., 373 U.S. 668 (1963); Monroe v. Pape, 365 U.S. 167 (1961).

so "If we were to sanction this intervention, we would expose every State criminal prosecution to insupportable disruption. Every question of procedural due process of law ... would invite a flanking movement against the system of State courts by resort to the federal forum .... [There would be opportunity] ... to subvert the orderly, effective prosecution of local crime in local courts." Stefanelli v. Minard, 342 U.S. 117, 123-24 (1951). "Every question of procedural due process might provide a basis for delay of state administration of justice." Note, 74 HARv. L. REV. 726, 738 (1961). 
with the real purpose of Congress in 1871,51 but also abrogates the necessity of totally disregarding section 2283 where the situation is deemed serious enough to warrant injunction..$^{52}$ Additionally, it applies a test which has some precedential predictability by utilizing general principles of comity in determining congressional intent. ${ }^{53}$ On the other hand, this may be too malleable a test to meet ordinary standards of legislative interpretation, and the application of a more mechanical test may win sway. The question will have to await decision either by Congress or the Supreme Court.

\footnotetext{
"1 See note 48 supra; text accompanying note 35 supra.

${ }^{3}$ The Baines court thought the issuance of an injunction would be a disregard of the anti-injunction statute. "[Section 2283] . . . is inapplicable in extraordinary cases in which an injunction ... is the only means of avoiding grave and irreparable injury. In our view, the congressional command ought to be ignored only in the face of the most compelling reasons . . . " 337 F.2d at 593 . (Emphasis added.)

cs See text accompany notes 37-39 supra.

"[W] then the circumstances warrant, the federal court, as a court of equity, should mould its process to accord with the factual situation. At times this will warrant an injunction against state court proceedings. The principals of comity and present $\$ 2283$ so recognize." MOORE, CoMmentary ON THE Judicial CODE 10.03 (49), at 415 (1949). It has been suggested that the best solution to the noninterference problem would be to repeal $\$ 2283$ and allow comity to govern completely. Comment, 35 GaLIF. L. REv. 545, 563 (1947).
} 